Article

\title{
Drone Geologic Mapping of an Active Sand and Gravel Quarry, Desoto County, Mississippi
}

\author{
Caroline Behrman ${ }^{1}$, Roy Van Arsdale ${ }^{1, *}$, Youngsang Kwon ${ }^{1}{ }^{\circledR}$, Kerry Stockslager ${ }^{2}$, \\ Dave Leverett ${ }^{3}$ and David Lumsden ${ }^{1}$ \\ 1 Department of Earth Sciences, University of Memphis, Memphis, TN 38152, USA \\ 2 901Drones, Memphis, TN 38120, USA \\ 3 Memphis Stone and Gravel Co., Memphis, TN 38106, USA \\ * Correspondence: rvanrsdl@memphis.edu; Tel.: +1-(901)-678-4356
}

Received: 1 July 2019; Accepted: 12 July 2019; Published: 15 July 2019

check for updates

\begin{abstract}
Aerial drone photography of an active pit within a sand and gravel quarry in DeSoto County, Mississippi, was conducted to better understand the Upland Complex, which is a high-level Pliocene terrace of the Mississippi River. The Upland Complex is of great interest economically, as it is the primary source of sand and gravel for Memphis, Tennessee and the surrounding region. The pit dimensions were approximately $820 \mathrm{ft}(250 \mathrm{~m})$ by $655 \mathrm{ft}(200 \mathrm{~m})$ and 79-ft $(24 \mathrm{~m})$ deep upon completion of the mining. Eight 3-D models of the pit were made at different times to illustrate the mining progression. Oblique and horizontal stereo aerial photography of the highwalls was conducted to produce 3-D models and high-resolution photomosaics of the highwalls for geologic mapping and interpretation. The mapped highwall geology included Pliocene Mississippi River bars consisting of sand, sand and gravel, and gravel ranging in thickness from $2 \mathrm{ft}(0.6 \mathrm{~m})$ to $32.8 \mathrm{ft}(10 \mathrm{~m})$, with variable cross-bed dip directions suggesting a meandering river environment of deposition. Pleistocene loess overlies the Pliocene sediment. The highwalls also revealed northerly-striking late Pliocene or Pleistocene tectonic folding, faulting, and probable earthquake liquefaction in northwestern Mississippi, where no Pliocene or Quaternary tectonic deformation had previously been reported. This study demonstrated Drone aerial photography as a quick, low cost, and safe means to study poorly accessible open-pit mining and to help understand the geology of the lower Mississippi River Valley.
\end{abstract}

Keywords: drone; geology; quarry; gravel; sand; upland complex; mapping; Agisoft; 3-D model

\section{Introduction}

The central United States is host to one of the largest drainage basins in the world, the Mississippi River. Today, the Mississippi River has depths of up to $100 \mathrm{ft}(30.5 \mathrm{~m})$ and is 2350 miles $(3,781 \mathrm{~km})$ long. The river, however, has a long and complex history [1-3], with some profound changes occurring during the Pliocene and Pleistocene [4-9].

A remnant of the ancestral Mississippi River floodplain is the ( 3.2 Ma) Pliocene [10] Upland Complex (UC) deposit, a high-level sand and gravel river terrace that is discontinuously preserved on interfluves adjacent to the modern Mississippi River in Illinois, Missouri, Kentucky, Tennessee, Arkansas, Mississippi, and Louisiana (Figure 1). Geologists have mapped the UC and use this information to better understand the Pliocene Mississippi River [7-9]. Sand and gravel companies are particularly interested in understanding the distribution and thickness of this deposit because it is the major commercial source of sand and gravel along the lower Mississippi River [11]. 


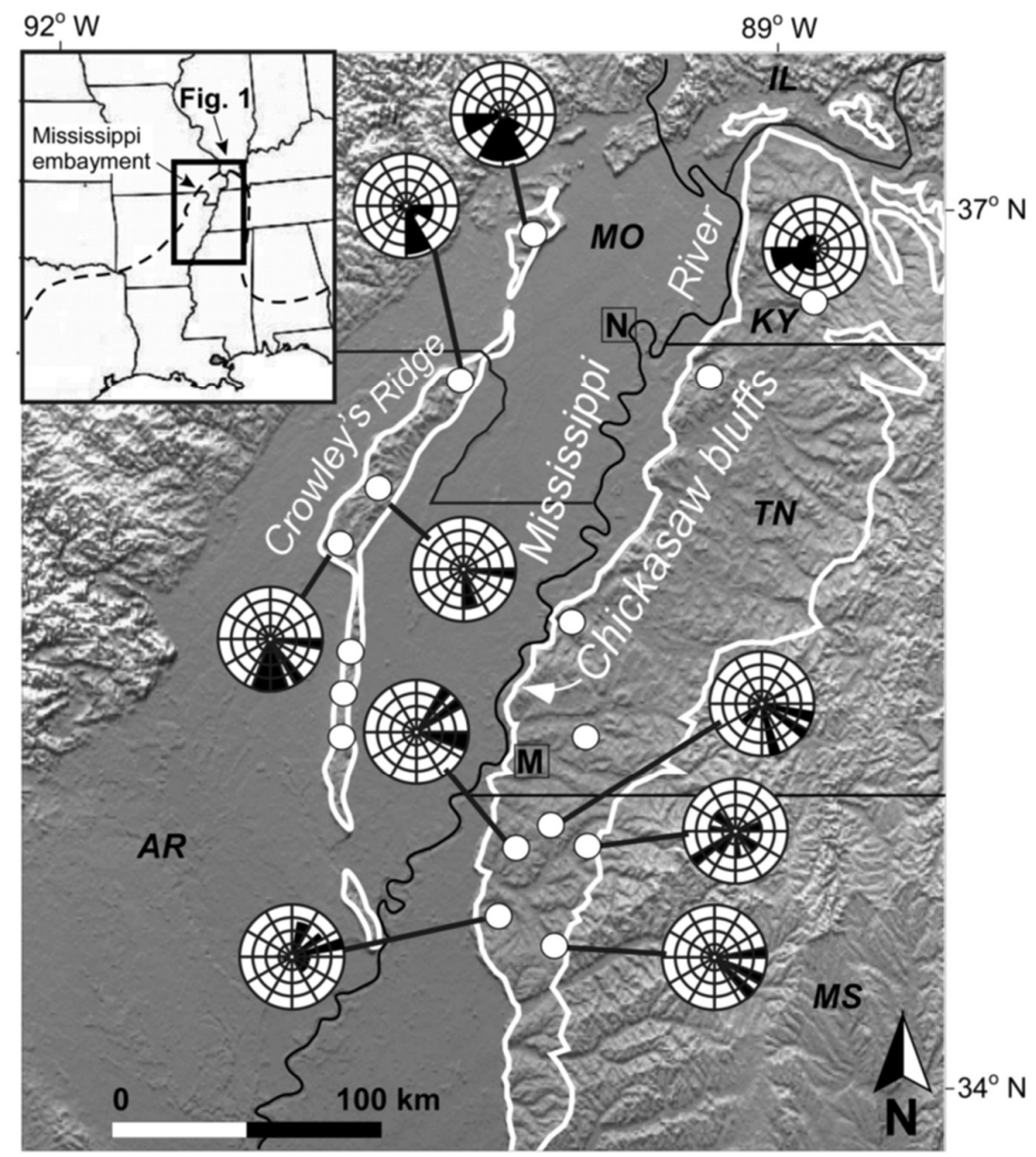

Figure 1. The white lines bound the distribution of the subsurface Pliocene Upland Complex that is buried by surface Pleistocene loess. The white dots are quarry sites and the polar diagrams record cross-bedding dip directions measured in the quarries (adapted from [8]).

The UC (also called the Lafayette Gravel, Mounds Gravel, or pre-loess gravel) is interpreted to be the remnant of a deposit of the Pliocene Mississippi River that once formed a continuous blanket up to 492-ft (150 m) thick, $\geq 62$ miles ( $100 \mathrm{~km}$ ) east-west from the Chickasaw Bluffs in western Tennessee to at least Crowley's Ridge in eastern Arkansas, and 435 miles $(700 \mathrm{~km})$ north-south along the Mississippi River from northern Illinois to southern Louisiana (Figure 1) [4,5,7-9,12-16]. Sea level decline during the Pleistocene resulted in an incision by the Mississippi River that isolated the UC as an eroded high-level terrace [4,7]. The UC disconformably overlies Eocene formations and is disconformably overlain by Pleistocene loess.

The UC primarily consists of brown to very pale brown (Munsell color 7.5 YR 4/6 to 10 YR 8/6) massive bedded well-rounded chert pebble gravel and coarse quartz sand (Figure 2) [9]. Gravel clasts are almost entirely chert with some polycrystalline quartzite (15\%). Chert clasts are stained with a surficial coating of goethite $(\mathrm{FeO}(\mathrm{OH})), 1.0-2.0 \mathrm{~mm}$ thick. The red-brown goethite staining shows no percussion marks, which indicates that the brown stain is post-depositional. Smaller clasts $(12 \mathrm{~cm})$ are frequently brown stained throughout or are partially or completely replaced by goethite. Common unstained clasts vary in abundance, without an observable geographic pattern [9].

The UC is of great interest, both geologically and economically. Studying the distribution and deposition of the UC has helped geologists understand the evolution of the lower Mississippi River Valley. The UC is also economically valuable, as it is the primary source of sand and gravel for Memphis, Tennessee and the surrounding region (Figure 1). Having a local source of gravel keeps construction costs low, so it is sought by mining companies particularly near cities. This research 
project was undertaken to evaluate the use of drone photography for mapping the stratigraphy of the UC exposed in an active quarry in DeSoto County, Mississippi and for photographing quarry excavation throughout the life of one of the quarry's pits (Figure 3).
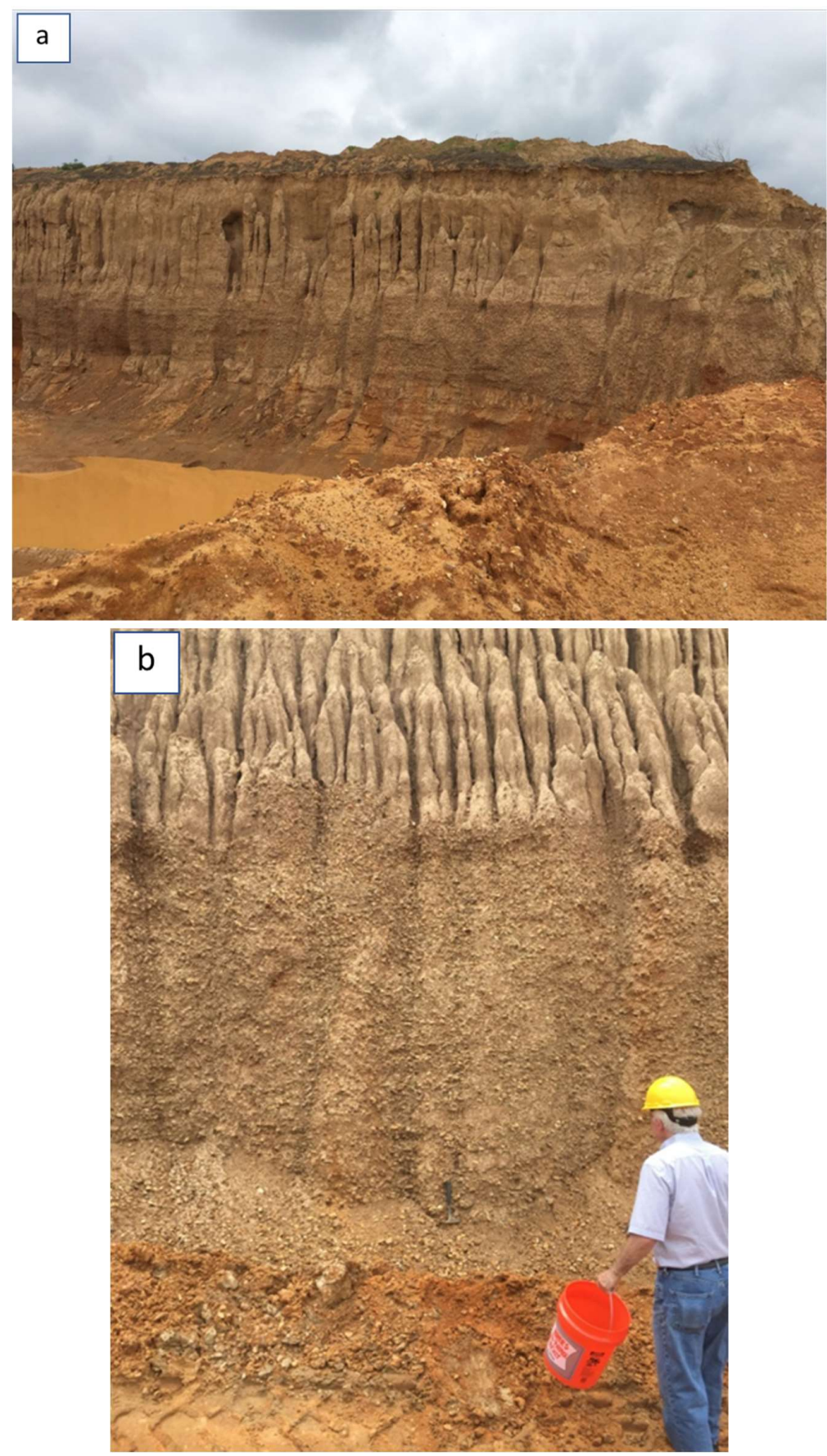

Figure 2. (a) A portion of the Upland Gravel pit in the DeSoto County, Mississippi sand and gravel quarry. (b) Close-up of the surface loess (rills) and underlying Upland Complex sand and gravel.

Unmanned Aerial Vehicle (UAV) technology, particularly drones, is increasingly valuable in geologic investigations [17,18]. Drone technology allows for safe study of difficult-to-access or hazardous areas and drones have been important in risk assessment and management [19]. Quarry highwalls are especially hazardous due to possible collapse and falling rocks. Because physical access to quarry highwalls is a safety concern, physical sampling of the highwall sediment is often not permitted by quarry management. 

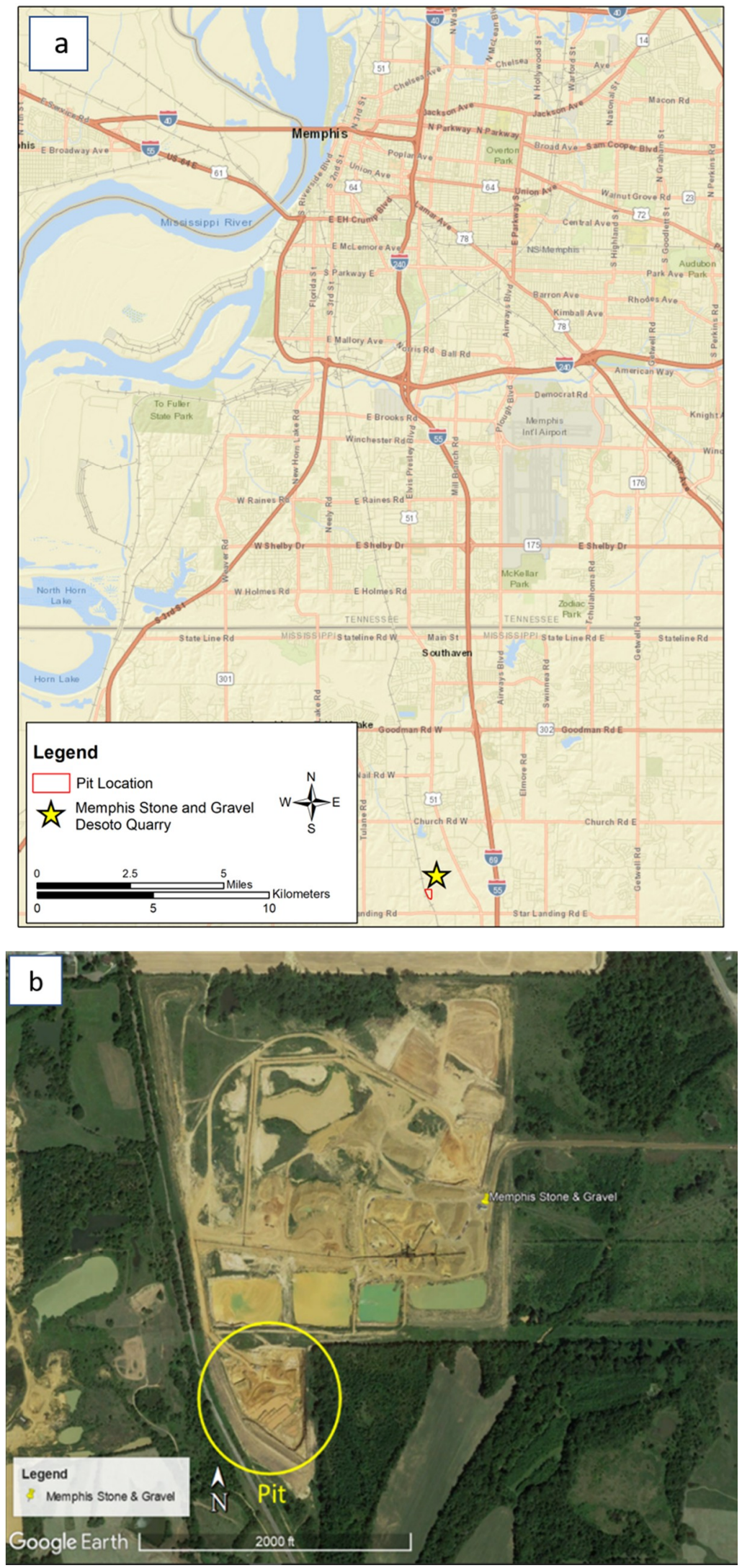

Figure 3. (a) Map of The Memphis Stone and Gravel quarry (yellow star) in Desoto County, Mississippi south of Memphis, Tennessee. (b) Google Earth image of the Desoto County, Mississippi quarry. Drone flights for this project were confined to the circled pit. 
This study focused on a sand and gravel quarry in DeSoto County, Mississippi. Specifically, this research was conducted in the pit of an active quarry, mined by Memphis Stone and Gravel Company in Southaven, Mississippi (Figure 3), which is being mined in the Pliocene UC deposit. Our primary objectives were to assess the utility of drone photography to map the three-dimensional geology exposed in the quarry pit to better understand its environment of deposition and to provide information that may help in the future exploration of the sand and gravel deposit regionally.

\section{Materials and Methods}

Drones and other forms of UAVs allow for high-definition aerial photography and are useful for imaging inaccessible or hazardous areas such as $+100-\mathrm{ft}(+30.5 \mathrm{~m})$ high quarry walls (highwalls) (Figure 2). We conducted a total of eight drone photography surveys between May 2017 and May 2018 as the sand and gravel pit was actively being mined. To obtain the best consistent light conditions for mapping, as well as to minimize shadow effects for the interior highwalls, we carried out all the flights between 11:00 and 13:00, with a clear or fully overcast sky, minimal highwall shadow, and minimal wind. In this study we used geometric-mathematical reconstructions of individual points to reconstruct the photographs in a three-dimensional (3-D) space [19]. From UAV photogrammetry, point clouds, orthomosaics of the highwalls, and digital 3-D models were constructed (Figures 4 and 5).

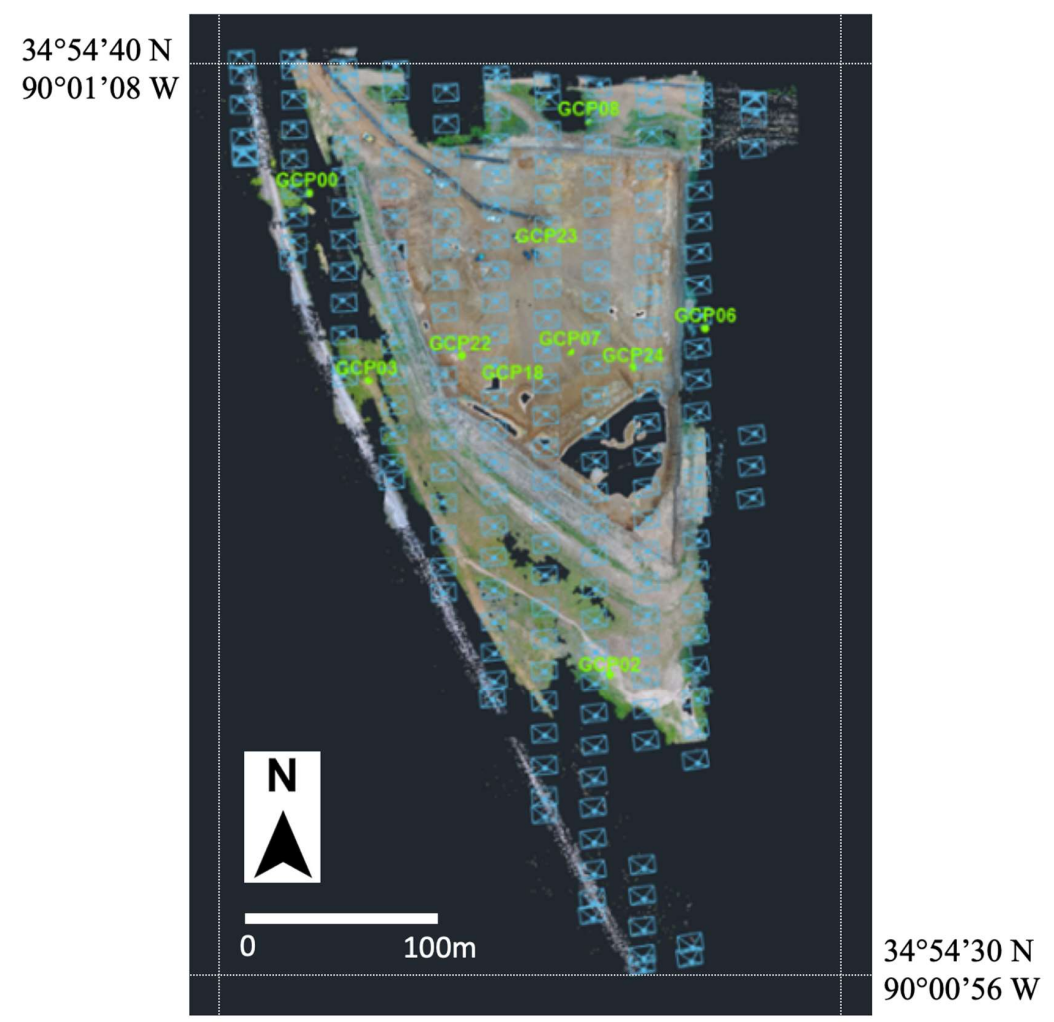

Figure 4. Flight plan of drone for mapping using 3-D Survey. The blue points indicate individual photographs used to create a point cloud of the pit. Ground control survey points are shown in green.

For this study, we used a drone for several reasons. Drones are a cost effective and rapid method for safely photographing large areas that allow for pre-flight elevation and flight path programming. Many areas of the pit were unapproachable because of water in the pit and the potentially unstable near-vertical highwalls. The drone allowed access to areas that would not allow a fixed-wing aircraft because of right-angle bends in the highwall. Drone technology permitted various photograph look directions, which allowed us to photograph the near-vertical highwall faces. The drone photography also allowed us to quickly and accurately create digital surface models, orthophotos, highwall photomosaics, and 3-D models from the imagery [18]. 


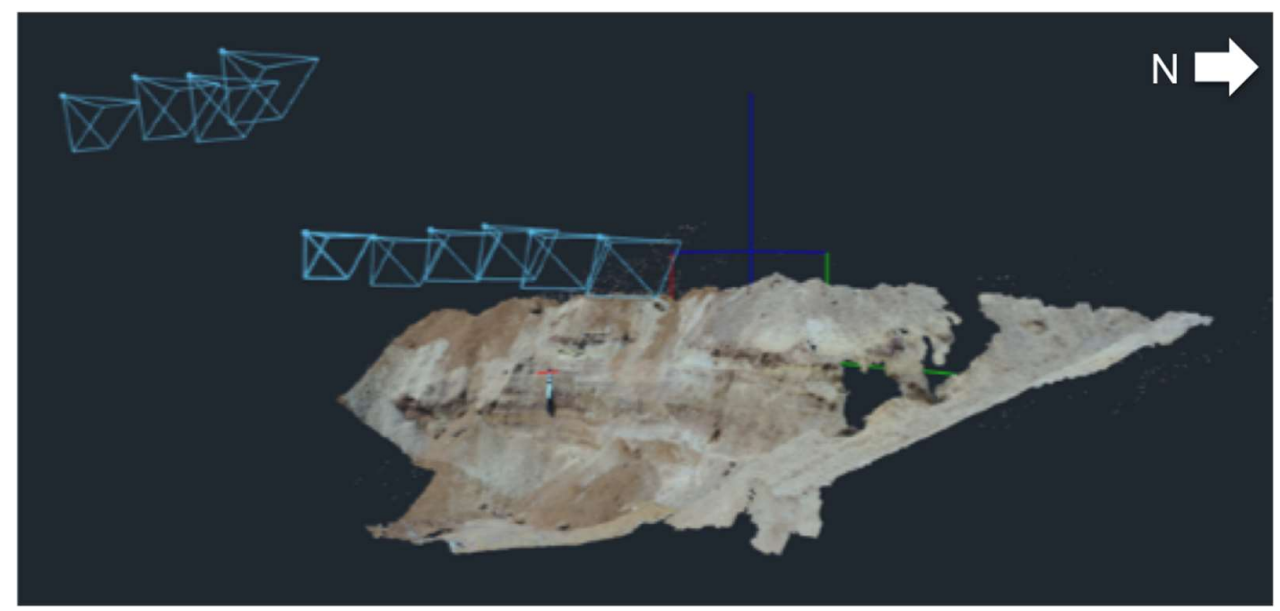

Figure 5. Example point cloud rendering of an interior highwall from oblique photograph flight using 3-D Survey. Note the $1.5 \mathrm{~m}$ wooden rod scale.

In this research, we used a Phantom 4 Pro drone equipped with a 1-inch 20-megapixel CMOS sensor (400 $\mathrm{nm}$ to $700 \mathrm{~nm}$ RGB range; model number: CP.PT.000689) with a field of view of $84^{\circ}$ or $8.8 \mathrm{~mm}$ ( $35 \mathrm{~mm}$ format equivalent: $24 \mathrm{~mm}$ ). The Phantom model has a maximum flight time of $30 \mathrm{~min}$ and can be either controlled manually or operated fully autonomously using a predefined Global Positional System (GPS) path. The camera was mounted on the base of the drone and could be oriented to photograph in any direction. Vertical, oblique, and horizontally oriented photographs were taken at different distances from the highwall to determine good flight distances and look directions for geologic analysis.

All the drone flights were conducted by 901Drones of Memphis, Tennessee. Ten permanent ground control points (GCP) were placed around the exterior and the interior of the pit, with coordinates surveyed using a GNSS receiver (model: Trimble R8s) with a static maximum precision of $8 \mathrm{~mm}$ and $15 \mathrm{~mm}$ for horizontal and vertical accuracy, respectively. GCPs were used to provide topographic control of the 3-D models and to calculate photogrammetric accuracy (Figure 4). The Root Mean Square Error (RMSE) was calculated as the differences between the $x-y-z$ positions of the ten GCPs and their $x-y-z$ positions on the georeferenced orthophoto. Several methods were tested to determine the most effective parameters for flying the drone. For vertical 3-D mapping of the pit, the drone was flown at $200 \mathrm{ft}(61 \mathrm{~m})$ above the quarry floor with the camera pointed directly down, and the drone was launched and controlled from within the pit. Approximately 350 images were required to cover the entire pit area and to capture the GCPs on the pit's perimeter. For analysis of the highwalls, two photography perspectives were employed. Drone photography was taken at $90^{\circ}$ (horizontal) angles within 25-30 ft (7.6-9.1 m) of the highwalls and obliquely at $45^{\circ}$ at $20 \mathrm{ft}(6.1 \mathrm{~m})$ above the highwall top. A $1.5 \mathrm{~m}$ wooden scale was placed on the highwalls prior to horizontal and oblique aerial photographing. All the photos had a minimum of $60 \%$ overlap for subsequent 3-D modeling and stereographic viewing to ensure that every part of the area was covered in a minimum of three overlapping images.

Two software packages were used to process the drone photography in this study: 3D Survey (https://www.3dsurvey.si) and Agisoft Photoscan Professional (https://www.agisoft.com). The 3D Survey software is a point-cloud processing software that was used to generate vertical and oblique 3-D models and orthophotos of the quarry pit. Agisoft Photoscan was used to create orthomosaics and 3-D models of the near-vertical highwalls for geologic "cross-section" mapping (Figures 4-8). 

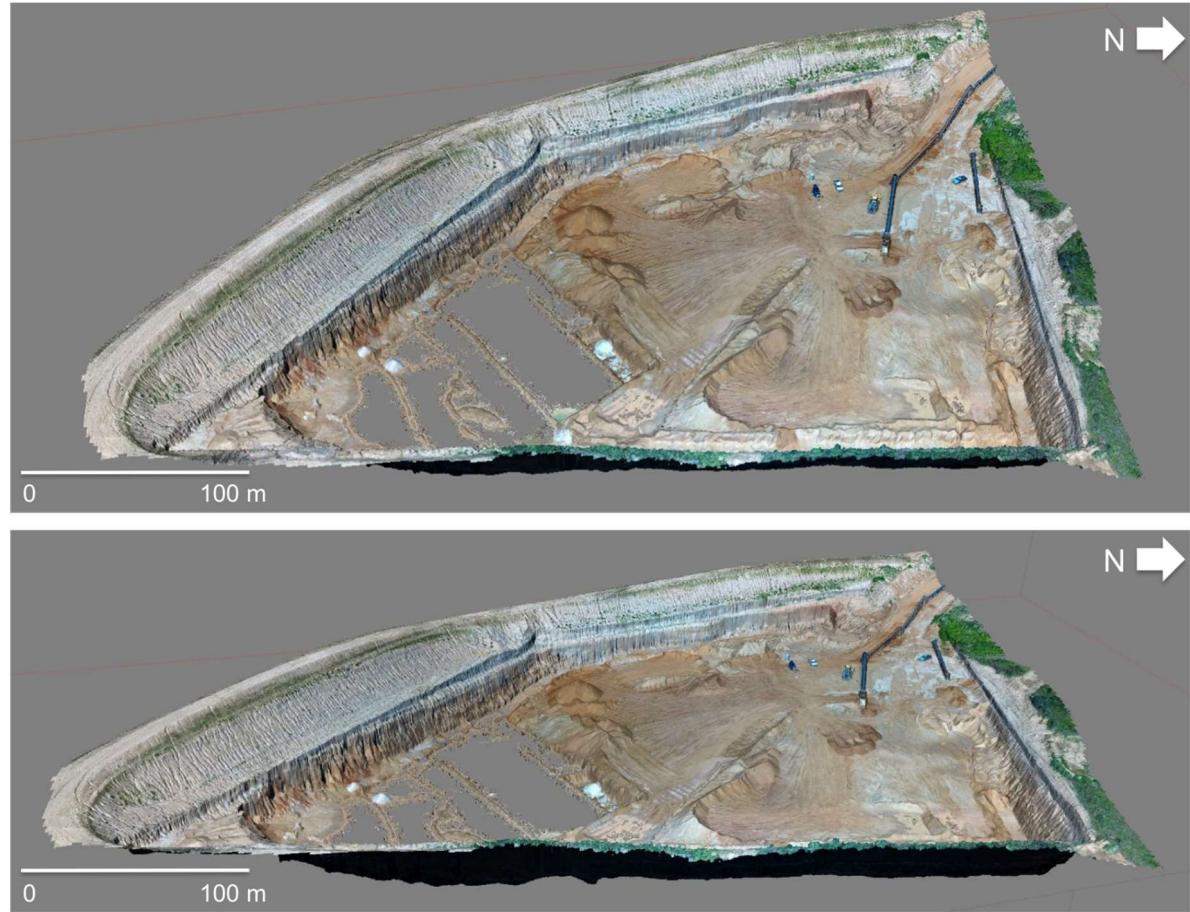

Figure 6. Rotated views of quarry pit using 3D Survey software.

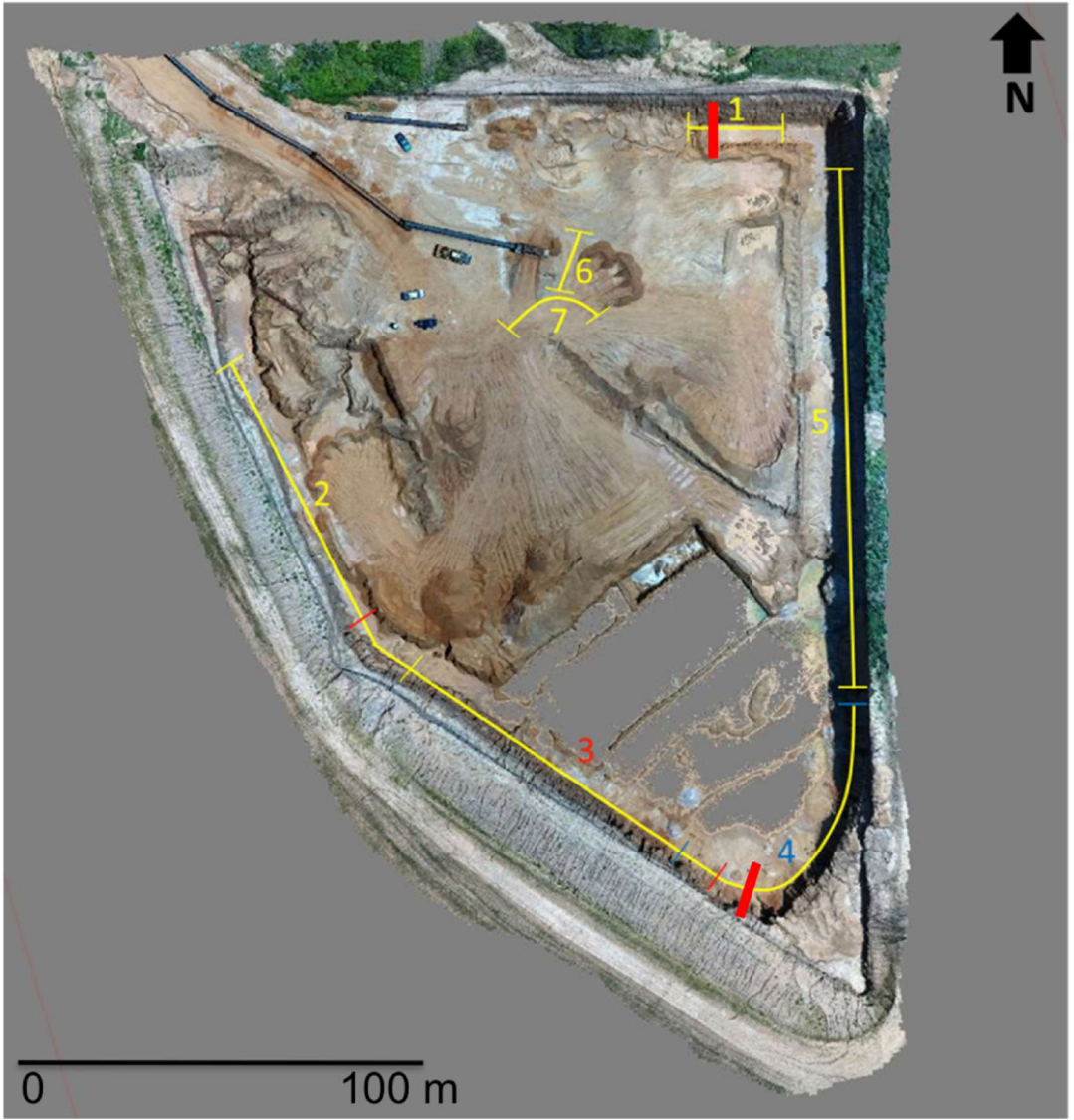

Figure 7. Map view of 3-D model of the quarry pit using 3D Survey software. The numbered yellow lines are the highwalls that were geologically interpreted. The short colored lines that cross the exterior highwalls mark the ends of the highwall with the same colored number. The short bold red line that bisects highwalls 1 and 4 is the location of the fault in Figures 8 and 11. 

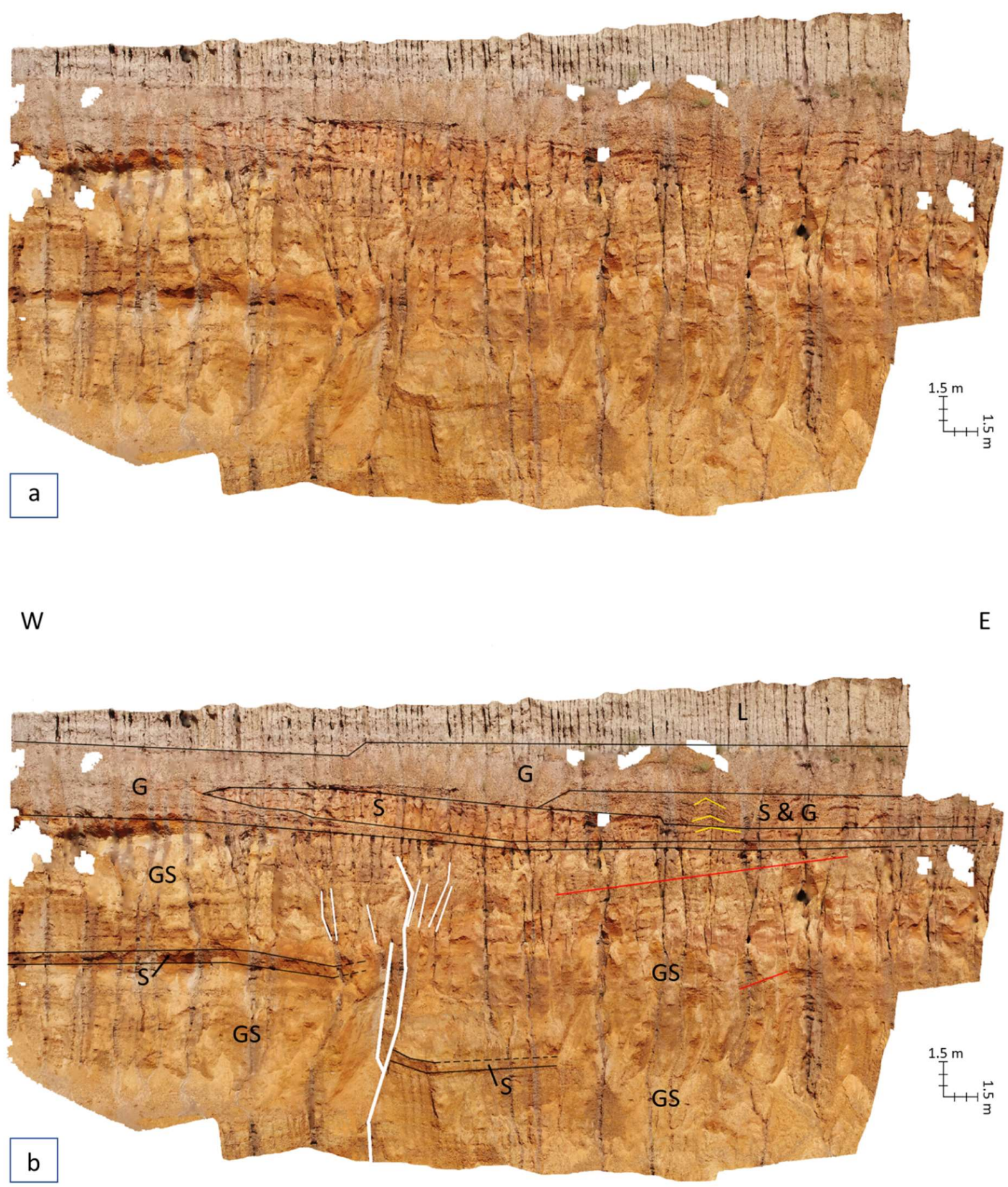

Figure 8. (a) Orthomosaic of highwall 1, located in Figure 7, photographed $25 \mathrm{ft}(7.6 \mathrm{~m})$ from the highwall. (b) Sedimentary unit boundaries highlighted by the black lines, cross-bedding with the red lines, faults with the thick white lines, and fractures with the thin white lines. The yellow lines identify liquefaction that may have been caused by the adjacent faulting and associated earthquake shaking. $\mathrm{L}=$ loess, $\mathrm{S}=$ sand, $\mathrm{GS}=$ gravelly sand, $\mathrm{G}=$ gravel. The white gaps indicate a lack of overlap between photos caused by shadows.

\section{Results}

During eight visits to the quarry, aerial drone mapping flights were conducted to track the mining progress and to photograph the temporary interior highwalls. We do not herein present the mapping history of the pit but focus on the highwall geology revealed in the drone photography. 
Several 3-D models were constructed of both the entire pit and of the individual highwalls. The quarry pit models were used to track the mining progress to show newly formed interior highwalls (Figures 6 and 7). Our geologic interpretation of the highwalls was based on our experience of mapping these same units in previous research [4,9]. The RMSEs for all eight 3-D models were within the accuracy of $2 \mathrm{~cm}$ and $12 \mathrm{~cm}$, for horizontal and vertical, respectively. The 3-D models of the highwalls were converted into two-dimensional orthomosaic photographs that were used for geologic interpretation (Figures 8-14). The image spatial resolution (i.e. ground sample distance) for the highwalls was approximately $0.25 \mathrm{~mm}$ per pixel and the orthomosaic photographs (Figures 8-14) we present had minor holes where the overlap of the original images was not sufficient.

SE

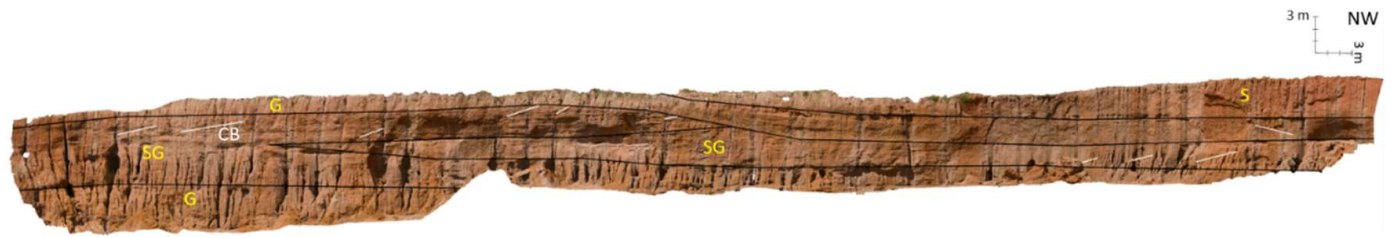

Figure 9. Highwall 2. The apparent monocline at the SE end (left) of the mosaic is an artifact of a bend in the highwall (Figure 7). The dashed white line marks the fold hinge artifact.

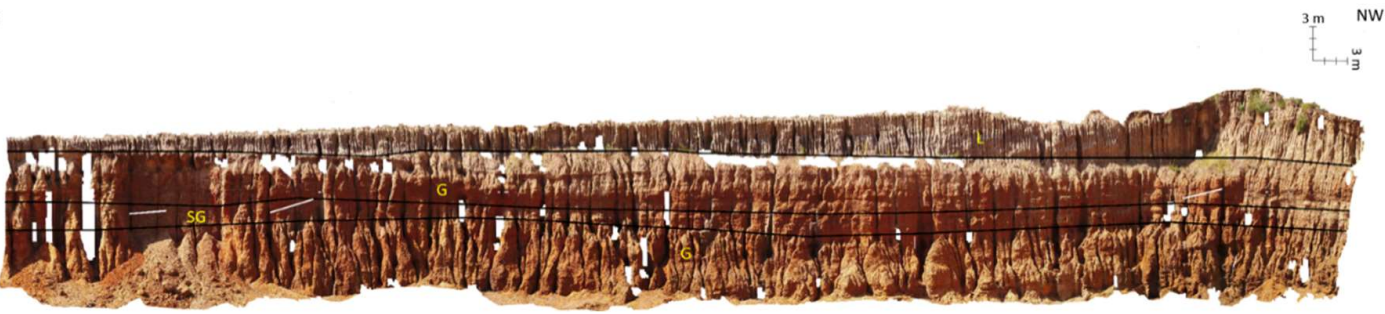

Figure 10. Highwall 3. The apparent monocline at the NW end of the mosaic is an artifact of a bend in the highwall (Figure 7).

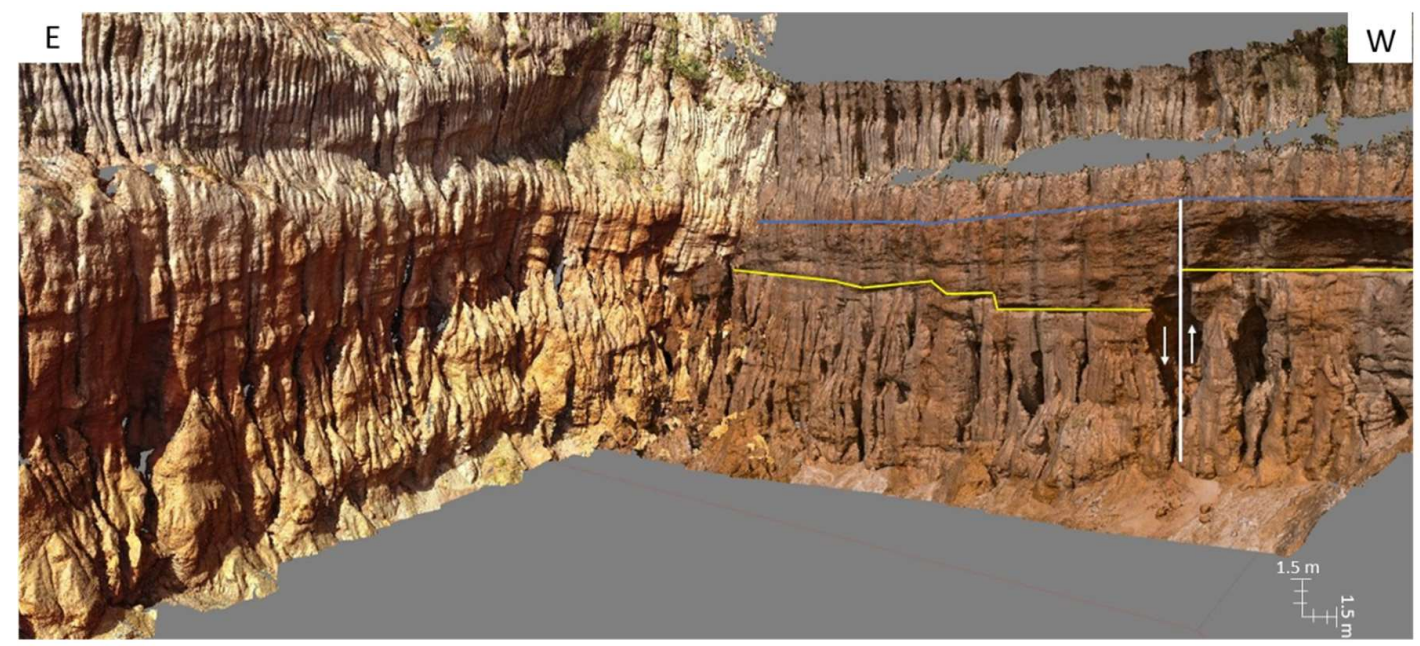

Figure 11. Highwall 4. Bend in highwall produces an apparent fold in the strata in the middle of this photomosaic. A possible down-to-the-east fault is mapped as a vertical white line.

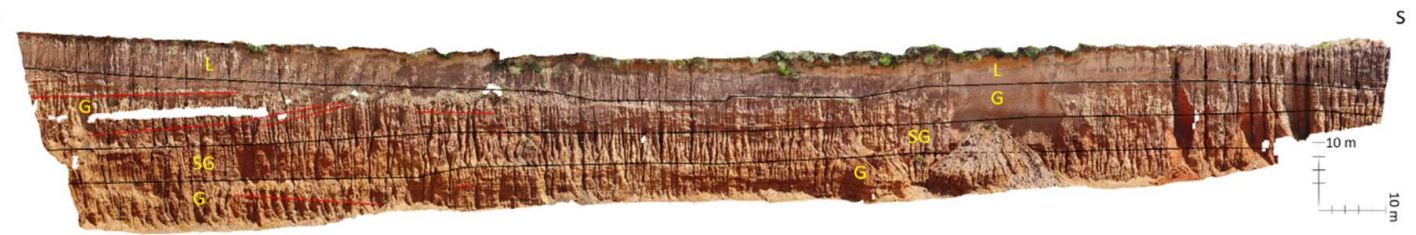

Figure 12. Highwall 5. 


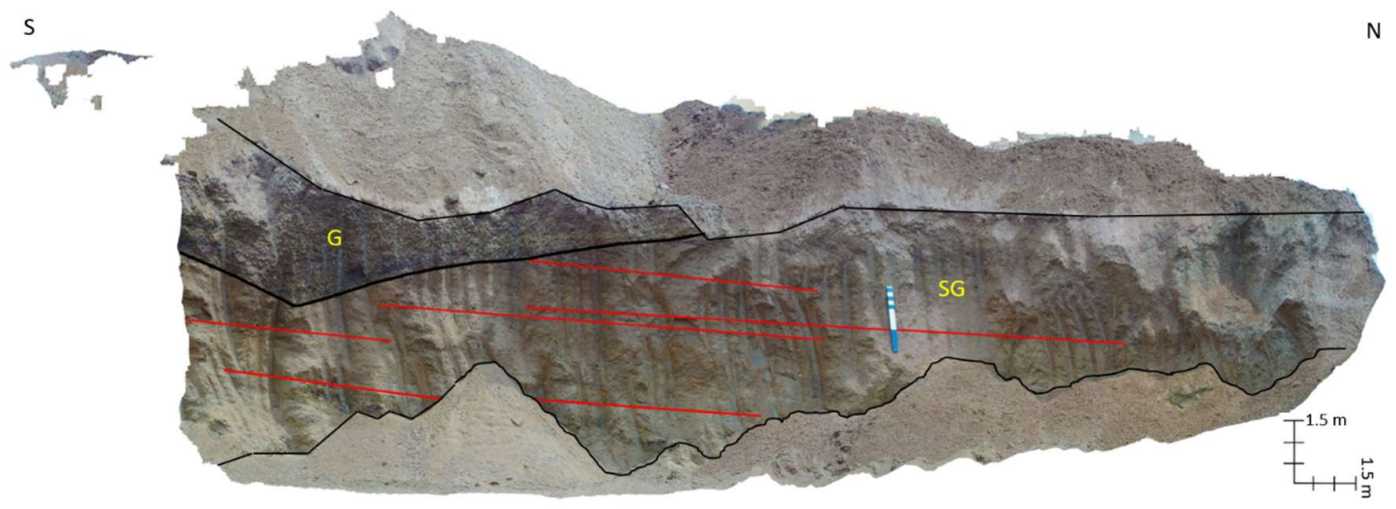

Figure 13. Highwall 6. Cross-bedded sandy gravel is a minimum of $16.4 \mathrm{ft}(5 \mathrm{~m})$ thick.

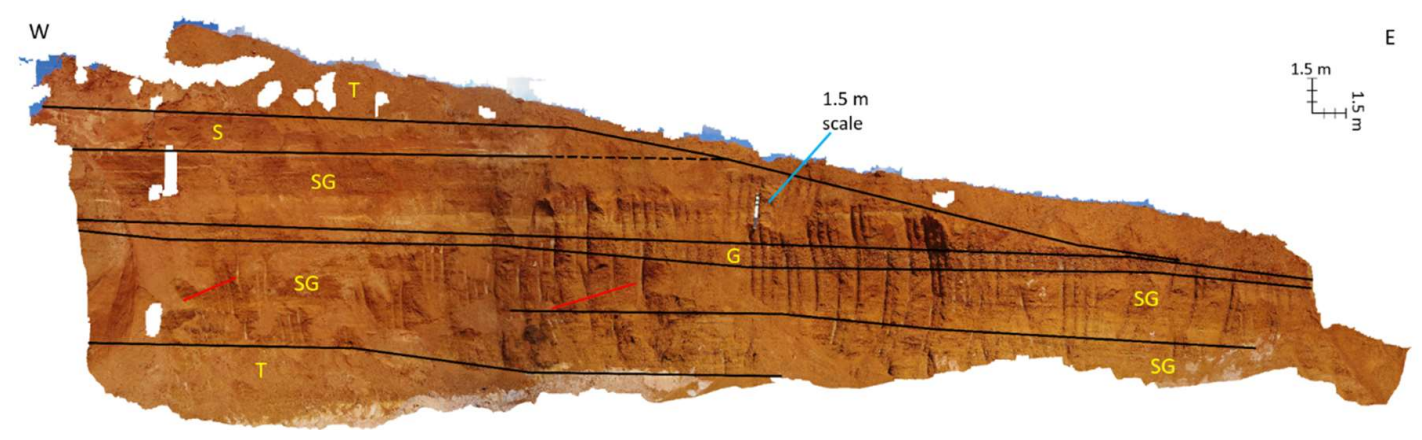

Figure 14. Highwall 7.

Photomosaics of five of the pit's exterior highwalls and two interior highwalls were made (Figure 7). Only two interior highwalls could be geologically mapped because most of the interior highwalls were covered by colluvium. During the mining, temporary berms were constructed immediately above the interior highwalls for safety purposes. Unfortunately, wash-over from the berms buried or obscured most of the in situ strata in the interior highwalls, so they could not be geologically mapped.

The exterior highwalls averaged $52 \mathrm{ft}(16 \mathrm{~m})$ in height and revealed the stratigraphy and structure of the pit area very well (Figures 8-14). The stratigraphy of the highwalls consists of tan Pleistocene loess (silt) overlying reddish brown Pliocene UC fluvial sand and gravel. The sands and gravels are essentially flat-lying river bar deposits with cross-beds (Table 1). Only the apparent dip directions of the cross-beds can be obtained from the highwall surfaces but the cross-beds dip in all directions, indicating a full azimuth of paleo-flow directions that suggests a meandering flow pattern.

Table 1. Highwalls and their orientations given in the second row. The subsequent rows are cross-bed apparent dip values measured within the highwall photomosaic.

\begin{tabular}{cccccc}
\hline Highwall 1 & Highwall 2 & Highwall 3 & Highwall 5 & Highwall 6 & Highwall 7 \\
\hline $\mathrm{E}$ & $\mathrm{N} 28 \mathrm{~W}$ & $\mathrm{~N} 57 \mathrm{~W}$ & $\mathrm{~N}$ & N20E & N50E \\
$9 \mathrm{~W}$ & $15 \mathrm{NW}$ & $7 \mathrm{SE}$ & $20 \mathrm{~S}$ & $5 \mathrm{NE}$ & $25 \mathrm{SW}$ \\
$23 \mathrm{~W}$ & $15 \mathrm{SE}$ & $13 \mathrm{SE}$ & $13 \mathrm{~N}$ & $3 \mathrm{NE}$ & $18 \mathrm{SW}$ \\
& $16 \mathrm{SE}$ & $5 \mathrm{SE}$ & $12 \mathrm{~N}$ & $4 \mathrm{NE}$ & $18 \mathrm{SW}$ \\
& $11 \mathrm{SE}$ & & $13 \mathrm{~N}$ & $5 \mathrm{NE}$ & \\
$13 \mathrm{SE}$ & & $5 \mathrm{~S}$ & $8 \mathrm{NE}$ & \\
& $11 \mathrm{SE}$ & & $4 \mathrm{~S}$ & $4 \mathrm{NE}$ & \\
& $10 \mathrm{SE}$ & & & & \\
& $10 \mathrm{SE}$ & & & & \\
$5 \mathrm{SE}$ & & & & \\
& $5 \mathrm{SE}$ & & &
\end{tabular}




\section{Discussion}

\subsection{Highwall 1}

Highwall 1 is oriented west to east (Figure 7) with a north look direction in Figure 8. The highwall is 59-feet $(18 \mathrm{~m})$ to $72-\mathrm{ft}(22 \mathrm{~m})$ high and 144- $\mathrm{ft}(44 \mathrm{~m})$ long. The highwall stratigraphy is Pleistocene silt loess over UC fluvial sand and gravel. The sand and gravel have been divided into horizons of sand, sandy gravel, gravelly sand, and gravel based on the interpretation of the highwall photomosaic and the stereoscopic analysis of the overlapping photographs. Most of the stratigraphy in highwall 1 is near-horizontal, however, there is a steep west-dipping reverse fault in the middle of the highwall that has drag folding on both sides of the fault. Fault displacement is $13 \mathrm{ft}(4 \mathrm{~m})$ down-to-the-east, which is evident on a $2-\mathrm{ft}(0.6 \mathrm{~m})$ thick sand horizon. Near-vertical fractures exist adjacent to the uppermost portion of the fault. On the west (upthrown) side of the fault, the displaced sand and gravel unit has been eroded and buried by the overlying gravel unit, indicating that approximately $8 \mathrm{ft}(2.4 \mathrm{~m})$ of fault displacement occurred before deposition of the gravel. This same gravel unit is warped $5 \mathrm{ft}$ $(1.5 \mathrm{~m})$ down-to-the-east across the underlying fault, indicating post-gravel fault reactivation. On the eastern side of highwall 1 is minor anticlinal folding within the sand and overlying sandy gravel horizons. We believe this minor folding formed due to water ejection, probably during earthquake liquefaction that may have been coincident with the adjacent fault's second post-gravel displacement event. The overlying Pleistocene loess does not appear to be deformed.

\subsection{Highwall 2}

Highwall 2 trends south-north (Figure 7) and the look direction is to the west in Figure 9. This highwall is $17 \mathrm{ft}(5.3 \mathrm{~m})$ to 36- $\mathrm{ft}(11 \mathrm{~m})$ high, 354-ft $(184 \mathrm{~m})$ long, and exposes alternating beds of UC sand, sandy gravel, and gravel that range in thickness from $5.5 \mathrm{ft}(1.7 \mathrm{~m})$ to $11 \mathrm{ft}(3.4 \mathrm{~m})$. The river channel bars are generally flat-lying, with channel scour cut-and-fill evident in the upper center portion of the highwall. Near the southern portion of the highwall is an apparent 2-ft $(0.6 \mathrm{~m})$ down-to-the-south flexure whose hinge is marked with a white dashed line in Figure 9. This apparent monocline is an artifact of the bend in the highwall (Figure 9). This interpretation is based on the fact that the southern portion of highwall 2 is shown in the northern end of highwall 3. However, in highwall 3, the northern limb of the apparent monocline dips to the north (Figure 10).

\subsection{Highwall 3}

Highwall 3 trends south-north (Figure 7$)$, is 390-ft $(119 \mathrm{~m})$ long, $41 \mathrm{ft}(12.6 \mathrm{~m})$ to $55-\mathrm{ft}(16.8 \mathrm{~m})$ high, and the look direction is to the west in Figure 10. Highwall 3 is the southern continuation of highwall 2 and overlaps the highwall 2 photomosaic (Figure 7). In this highwall, the strata consist of loess overlying alternating sand, sandy gravel, and gravel river bar sediments that range in thickness from $3.2 \mathrm{ft}(1 \mathrm{~m})$ to $21.3 \mathrm{ft}(6.5 \mathrm{~m})$.

\subsection{Highwall 4}

Highwall 4 is the east-to-west southern margin of the pit (Figure 7) and the look direction in Figure 11 is to the south. This highwall is capped by loess and is roughly $55-\mathrm{ft}(16.7 \mathrm{~m}) \mathrm{high}$. In this photomosaic, we combined two data sets. As is obvious in Figure 11, this did not work well. The highwall drone flights were conducted at different solar angles because of their different facing directions due to the major bend in the highwall, resulting in poor photo alignment and a distorted 3-D model. However, the stratigraphy can still be determined to consist of loess overlying river sand, sandy gravel, and gravel bars. There is an apparent down-to-the-southwest monocline in the center of the photomosaic where the highwall makes a sharp bend (Figure 11). This apparent monocline is an artifact of the mosaic construction since this flexure is not seen in the pit.

In the western portion of highwall 4 is an apparent down-to-the-east fault. We highlighted the stratigraphy and interpreted the fault, but the fault plane is not visible because the fault zone appears 
to have been eroded. However, we believe that the fault in highwall 4 is indeed present and is the same fault as in highwall 1, based on the following observations: (1) the faults in highwalls 1 and 4 appear to be north-trending and on strike, (2) both faults have down-to-the-east displacement, and (3) the fault at both locations has $3 \mathrm{~m}$ of apparent displacement.

\subsection{Highwall 5}

Highwall 5 is the north-to-south photomosaic of the pit's eastern margin and is $574-\mathrm{ft}(175 \mathrm{~m})$ long and 56-ft (17 m) to 85-ft ( $26 \mathrm{~m}$ ) high (Figures 7 and 12). The sediments in the highwall are loess overlying the river bars of sand, sandy gravel, and gravel that are generally flat-lying. There is an apparent $2.3 \mathrm{ft}(0.7 \mathrm{~m})$ down-to-the-south flexure in the southern portion of highwall that is a mosaic artifact due to a bend in the highwall (Figure 7).

\subsection{Highwall 6}

Highwall 6 is a southwest-northeast interior highwall (Figures 7 and 13). This $12-\mathrm{ft}(3.6 \mathrm{~m})$ to $22-\mathrm{ft}(6.7 \mathrm{~m})$ high by $92-\mathrm{ft}(28 \mathrm{~m})$ long highwall illustrates northeast-dipping cross-bedding throughout a sandy gravel river bar that is a minimum 16-ft $(5 \mathrm{~m})$ thick. The overlying loess was removed at this site during the mining.

\subsection{Highwall 7}

Highwall 7 is a west-to-east interior highwall that is $10.5-\mathrm{ft}(3.2 \mathrm{~m})$ to $34-\mathrm{ft}(10.3 \mathrm{~m})$ high and $195-\mathrm{ft}$ (59 m) long (Figures 7 and 14). This highwall consists of flat-lying sand, sandy gravel, and gravel bar horizons with west-dipping cross-beds. Alluvial units range in thickness from 2 to $17 \mathrm{ft}(0.6$ to $5.3 \mathrm{~m})$. Loess was removed at this site during the mining. The apparent fold at the base of the western end of highwall 7 is not a fold but a contact between the in situ UC and colluvium at the base of the highwall.

\subsection{Recommendations}

More GCPs along the highwalls would increase 3-D model accuracy and would allow the determination of very accurate highwall photo scales, thereby removing the need to place a physical scale on the highwalls during drone photography. Interior highwalls were often covered by colluvium due to the mining practice of building a berm on the top of the highwall close to the highwall edge. Better photography of highwall stratigraphy could be obtained if berms were located at least $10 \mathrm{ft}(3 \mathrm{~m})$ from the highwall face so that berm sediment would not cascade down the highwall face and bury the stratigraphy.

It is preferable to photograph an entire highwall over a short period of time on a single day (Figure 13), which ensures similar light exposure and no highwall erosion or deposition between flights. We also believe that a $70-80 \%$ overlap between the photographs would result in better photomosaics and may allow the estimation of sediment particle size at any location within the pit. For example, it may be possible to conduct digital grain size analysis of the highwall stratigraphy, such as distinguishing between silt particles $(0.002$ to $0.05 \mathrm{~mm})$ and sand (greater than $0.05 \mathrm{~mm}$ ) from the highwall photography. To conduct such an analysis, a drone of the type used in this study should be very close to the highwall (less than $2 \mathrm{~m}$ ) so the image spatial resolution would be less than $0.05 \mathrm{~mm}$ per pixel and should have minimal shadows to avoid skewing object identification and particle size calculations.

We recommend that vertical flight lines be flown $<7 \mathrm{ft}(2 \mathrm{~m})$ from the highwall and that they be flown down the highwall whenever the highwall stratigraphy changes. This should provide adequate resolution for computer determination of highwall sediment grain size and perhaps aggregate quality [20-22]. 


\section{Conclusions}

Drone aerial photography provides a highly effective imaging system for open-pit mining and research of the exposed geology. Aerial drone mapping of the Mississippi River's Pliocene UC terrace in the Memphis Stone and Gravel active sand and gravel quarry has shown its utility in (1) recording mining progress, (2) identifying and quantifying sedimentary facies geometry, (3) estimating Pliocene Mississippi River paleocurrent directions using cross-bed apparent dip directions, (4) identifying geologic structures, including faults, fractures, folds, and liquefaction, and (5) preserving a digital stereoscopic record of the ancient Mississippi River alluvium that is removed in the mining process (Figures 7-14 and Supplementary Materials).

During the acquisition of the drone photography, no geologic structure was evident in the quarry highwalls. However, the orthomosaics of the highwalls provided an excellent mapping base wherein a fault became evident. The reverse faulting, folding, and liquefaction in highwall 1 demonstrates a deformation that we believe is tectonic (Figure 8). An interpretation of tectonic faulting is preferred over geomorphic slumping because the fault has compressional reverse movement, drag folding in both the hanging wall and the footwall, cross-cutting relationships that demonstrate two periods of faulting and adjacent sediment liquefaction, which suggests coincident earthquake shaking. The fault in highwall 1 is interpreted to continue south and pass through highwall 4 . Thus, this study identified northerly-striking late Pliocene or Pleistocene faulting that had not been previously documented in DeSoto County, Mississippi. Based on the relationship between fault displacement and earthquake magnitude, an 8-ft (2.4 m) fault displacement could produce a moment magnitude 7.3 earthquake [23].

Supplementary Materials: The following are available online at https://doi.org/10.5281/zenodo.3333037, Supplementary S1: Powerpoint containing a 3-D photographic animation of the DeSoto County, Mississippi, sand and gravel pit studied in this research.

Author Contributions: Conceptualization, R.V.A.; methodology, C.B. and K.S.; software, C.B., K.S., and Y.K.; validation, C.B., K.S., and Y.K.; formal analysis, R.V.A. and Y.K.; investigation, C.B., D.L. (Dave Leverett), D.L. (David Lumsden), K.S., R.V.A., and Y.K.; resources, K.S. and R.V.A.; data curation, C.B., R.V.A., and Y.K.; writing-original draft preparation, C.B., D.L. (David Lumsden), and R.V.A.; writing-review and editing, C.B., D.L. (David Lumsden), K.S., R.V.A., and Y.K.; visualization, C.B. and R.V.A.; supervision, D.L. (Dave Leverett) and R.V.A.; project administration, D.L. (Dave Leverett), K.S., and R.V.A.; funding acquisition, R.V.A.

Funding: This research was funded by the DRONES Cluster at the FedEx Institute of Technology at The University of Memphis.

Acknowledgments: We wish to thank Memphis Stone and Gravel and Alan Parks for providing access and field support for this research and Brian Waldron for his surveying of our control points.

Conflicts of Interest: The authors declare no conflict of interest.

\section{References}

1. Cox, R.T.; Van Arsdale, R.B. Hotspot origin of the Mississippi embayment and its possible impact on contemporary seismicity. Eng. Geol. 1997, 46, 5-12. [CrossRef]

2. Cox, R.T.; Van Arsdale, R.B. The Mississippi embayment, North America: A first order continental structure generated by the Cretaceous superplume mantle event. J. Geodyn. 2002, 34, 163-176. [CrossRef]

3. Van Arsdale, R.; Cox, R. The Mississippi's curious origins. Sci. Am. 2007, 296, 76-82. [CrossRef] [PubMed]

4. Van Arsdale, R.B.; Bresnahan, R.P.; McCallister, N.S.; Waldron, B. The Upland Complex of the central Mississippi river valley: Its origin, denudation, and possible role in reactivation of the New Madrid seismic zone. In Continental Intraplate Earthquakes: Science, Hazard, and Policy Issues; Special Paper 425; Stein, S., Mazzotti, S., Eds.; Geological Society of America: Boulder, CO, USA, 2007; pp. 177-192.

5. Van Arsdale, R.B.; Cox, R.T.; Lumsden, D.N. Quaternary isostatic uplift in the Northern Mississippi embayment. J. Geol. 2019, 127, 1-13. [CrossRef]

6. Rittenour, T.M.; Blum, M.D.; Goble, R.J. Fluvial evolution of the lower Mississippi river valley during the last 100 k.y. glacial cycle: Response to glaciation and sea-level change. Geol. Soc. Am. Bull. 2007, 119, 586-608. [CrossRef]

7. Cupples, W.; Van Arsdale, R. The Preglacial "Pliocene" Mississippi river. J. Geol. 2014, 122, 1-15. [CrossRef] 
8. Cox, R.T.; Lumsden, D.N.; Van Arsdale, R.B. Possible relict meanders of the Pliocene Mississippi river and their implications. J. Geol. 2014, 122, 609-622. [CrossRef]

9. Lumsden, D.N.; Cox, R.T.; Van Arsdale, R.B.; Cupples, W.B. Petrology of Pliocene Mississippi river alluvium: Provenance implications. J. Geol. 2016, 124, 501-517. [CrossRef]

10. Van Arsdale, R.B.; Balco, G.; Bierman, P.R.; Rood, D.H.; Rovey, C.; Cox, R.T.; Lumsden, D.N.; Parks, A. The Pliocene Mississippi river. Geol. Soc. Am. Abstr. Program. 2014, 46, 228.

11. Van Arsdale, R.B.; Arellano, D.; Stevens, K.C.; Hill, A.A.; Lester, J.D.; Parks, A.G.; Csontos, R.M.; Rapino, M.A.; Deen, T.S.; Woolery, E.W.; et al. Geology, geotechnical engineering, and natural hazards of Memphis, Tennessee, USA. Environ. Eng. Geosci. 2012, 18, 113-158. [CrossRef]

12. Potter, P.E. The petrology and origin of the Lafayette Gravel: Part 1. Mineralogy and petrology. J. Geol. 1955, 63, 1-38. [CrossRef]

13. Potter, P.E. The petrology and origin of the Lafayette Gravel: Part 2. Geomorphic history. J. Geol. 1995, 63, 115-132. [CrossRef]

14. Saucier, R.T.; Snead, J.I. Quaternary Geology of the Lower Mississippi Valley. Scale 1:1,000,000; Geological Society of America, Inc.: Boulder, CO, USA, 1989; 1 sheet.

15. Autin, W.J.; Burns, S.F.; Miller, B.J.; Saucier, R.T.; Snead, J.I. Quaternary Geology of the Lower Mississippi Valley. Quaternary Nonglacial Geology: Conterminous, U.S.; Morrison, R.B., Ed.; Geological Society of America, Inc.: Boulder, CO, USA, 1991; Volume K-2, pp. 547-582.

16. Dockery, D.T.; Starnes, J.E.; Thompson, D.E.; Beiser, L. Rocks and Fossils Found in Mississippi's Gravel Deposit; Circular 7; Mississippi Office of Geology; Mississippi Department of Environmental Quality: Jackson, MS, USA, 2008; p. 24.

17. Blistan, P.; Kovanic, L.; Zeliznakova, V.; Palkova, J. Using UAV photogrammetry to document rock outcrops. Acta Montan. Slovaca 2016, 21, 154-161.

18. Salvini, R.; Masrorocco, G.; Seddaiu, M.; Rossi, D.; Vanneschi, C. The use of an unmanned aerial vehicle for fracture mapping within a marble quarry (Carrara, Italy): Photogrammetry and discrete fracture network modelling. Geomat. Nat. Haz. Risk. 2017, 8, 34-52. [CrossRef]

19. Chesley, J.T.; Leier, A.L.; White, S.; Torres, R. Using unmanned aerial vehicles and structure-from-motion photogrammetry to characterize sedimentary outcrops: An example from the Morrison Formation, UT, USA. Sediment. Geol. 2017, 354, 1-8. [CrossRef]

20. Graham, D.J.; Reid, I. Automated sizing of coarse-grained sediments: Image-processing procedures. Math. Geol. 2005, 37, 1-28. [CrossRef]

21. Warrick, J.A.; Rubin, D.M.; Ruggiero, P.; Harney, J.N.; Draut, A.E.; Buscombe, D. Cobblecam: Grain-size measurements of sand to boulder from digital photographs and autocorrelation analyses. Earth Surf. Process. Landf. 2009, 34, 1811-1821. [CrossRef]

22. Pina, P.; Lira, C. Sediment image analysis as a method to obtain rapid and robust size measurements. J. Coast. Res. 2009, 56, 1562-1566.

23. Wells, D.; Coppersmith, K. New empirical relationships among magnitude, rupture length, rupture width, rupture area, and surface displacement. Bull. Seismol. Soc. Am. 1994, 84, 974-1002.

(C) 2019 by the authors. Licensee MDPI, Basel, Switzerland. This article is an open access article distributed under the terms and conditions of the Creative Commons Attribution (CC BY) license (http://creativecommons.org/licenses/by/4.0/). 